\title{
Ma üüan sind armas Risti kihilkond... \\ Rahvaluulekogujate äratussõnad ja avalikkuse kõnetamine
}

\author{
KATRE KIKAS
}

\begin{abstract}
Üiijan veel kora armsad Jakubi kihelgona sugu venad ja õõed ärkakem omiti kora ülesse aeg on juba amu tööle hakata sest villi on valmis kübse ja tahab rutulist kogu panemist muitu kui vanaks jäeb siis puteneb ärra aeg on juba amu käes võtkem siis suled sirbite eest käte ja hakakem tööle kelel vähägi aega on kelel endal aega ei ole se ütelgu teistele mis ta teab, meie kihelgond on surr kui iggas valta üks korjaja hakaks siis on ka assi ja mõnes kohtas on vana varra õige külald, need valad on üsna terved alles nimelt Kergu, Kaisma, Kõnnu, Poravere Enge, Arre Sõrike ja Parasma, Vee, [---]

Auliku härrad palun nii lahke olla ja seda sõnumid ärra trükita lasta... (EKM ERA, H IV 2, 507/9 < Hindrik Lusik (1889))
\end{abstract}

Rahvaluulekogumise aktsioonid XIX sajandi lõpus olid tugevalt seotud avaliku kirjaliku ruumiga. Ajalehed ja rahvaluulekogumikud andsid võimaluse kogumistööalast infot levitada ja panustanud kogujaid esile tõsta; viimane võis olla nii mõnegi osaleja jaoks esimene avalikkusega suhestumise kogemus. Käesoleva artikli keskmes on nn äratussõnad - lühikesed tekstid, millega kogumistööga juba liitunud inimesed õhutasid teisigi suulist pärimust kirja panema. Leian, et äratussõnad on kõnekas näide tekstidest, mis võimaldasid rahvaluulekogujatel olla mitte üksnes avalikkusena kõnetatav, vaid avalikkuse kõnetaja.

Avalikkuse all mõistan mingit ühiste huvidega rühma, keda on võimalik ühiste eesmärkide nimel tegevusse rakendada (Gal, Woolard 2001: 8; Bauman 2001: 60). Avalikkuse tekke juures on oluline tehnoloogiline vahendus, samal ajal ei tähenda see toetumist „konkreetsele lugejaskonnale või vaatajaskonnale, vaid pigem rühmade või üksikisikute kujutamisele trükisõnas või muus massimeedias" (Gal, Woolard 2001: 8; vt ka Gal 2001: 33). Kuivõrd XIX sajandi eestikeelne avalikkus oli rahvuslikult meelestatud, on see lähedane Benedict Andersoni (2006) kujutletud kogukonna ideele: kujutletud kogukond on (näiliselt) kõigile avatud ning koosneb anonüümsetest ja võrdsetest üksikisikutest; selle toimimiseks on vaja peale ühendavate sümbolite ka (trüki)meediasüsteemi ning standardiseeritud kirjakeelt.

Ülo Valk on väitnud, et „folkloori olemasolu ühiskondlik teadvustamine ja massimeedia mõjukuse kasv kulgesid paralleelselt" (2008: 61). Esimene eestikeelne rahvaluule olulisust esile tõstev kirjutis (Jakob Hurda „Mida rahvamälestustest arvata”) ilmus samal 1871. aastal, kui Eesti Postimehes lõppes nn suur sulesõda (väljarändamise ja rahvakoolidega seotud poleemika) ja mida peetakse eesti avalikkuse sünnitähiseks (Jansen 2004: 83). Samasse aega jäid ka muud avalikkuse kujunemise jaoks märgilised sündmused: esimene üldlaulupidu ja rahvuslike organisatsioonide 
asutamine (Jansen 2004: 83), nn uue kirjaviisi jõulisem kasutuselevõtt (Kingisepp 2001: 12). Artiklis vaatlen Jakob Hurda 1888. aasta üleskutsetele „Paar palvid Eesti ärksamaile poegadele ja tütardele" järgnenud rahvaluulekogumise aktsioonist osavõtjate suhet avaliku ruumiga. Seega keskendun ajale, mil eestikeelne avalik sfäär (ja avalik huvi rahvaluule vastu) oli juba paarkümmend aastat vana.

Ehkki avalikkus ise näeb end kõikehõlmava ning kõigile avatuna, siis kõrvalt vaadates tuleb alati küsida, kes on välja jäetud ning kelle võimu selline konstruktsioon kindlustab (Gal 2001: 33; Hill 2001: 83). Ameerika antropoloog Jane H. Hill on rõhutanud avalikkuse piiride ambivalentsust ning toonud esile neli avalikkuse piiritlemise jaoks olulist aspekti: ruum (kus midagi kõneldakse), kõneleja (kelle sõnadel on avalikus ruumis mõjujõudu), teema (millest sobib rääkida) ning stiil (kuidas avalikkuses tuleb sõna võtta) (Hill 2001: 87-93). Selleks et sõnum avalikkuses töötaks, on vaja, et nii kõneleja isik, tema valitud stiil ja teema kui ka kõnelemispaik oleksid üheselt avalikkusega seostatavad. Rahvaluulekogumises on need aspektid võrdlemisi ambivalentsed. Tõsi, kui võtta arvesse kogumistöö korraldajate avalikke sõnavõtte ning trükis ilmunud jutukogumikke, siis võib öelda, et rahvaluulekogumine oli selgelt tollase avalikkuse osa. Võttes aga vaatluse alla rahvaluulekogujate kirjutised, ei ole pilt nii ühene: kuivõrd kogumistööd korraldati ajalehtede kaudu, tajusid kogujad selle töö raames kirjutamist avalikus kirjaruumis osalemisena, hoolimata sellest, et avaldamise võimalus oli väga väike. Selle ambivalentsuse esiletoomiseks olen varem nimetanud rahvaluulekogumise käigus kirjutamist poolavalikuks (Kikas 2017a: 587).

Avalikkuse piiri ambivalentsusega seoses tuleb aga esile veel üks äratussõnade aspekt: nad paiknevad kahe erineva rühma avaliku repertuaari piiril. Esiteks on nad seotud rahvaluulekogumise aktsioone ümbritseva tekstiväljaga, kuhu kuuluvad korraldajate aruanded ja üleskutsed, muud ajakirjanduses ilmunud rahvaluulealased kirjutised ning rahvaluuleväljaanded. Teiseks on äratussõnad nn rahvalikele kirjutajatele kättesaadava avaliku eneseväljenduse osa (mõiste kohta vt Kikas 2014). Iseenesest võiks kogu eestikeelset kirjakultuuri XIX sajandil käsitleda rahvalikuna - puudus ju sellel ametlik-institutsionaalne taust. Oma uurimustes olen siiski eristanud nn kultuurilist eliiti, kellel oli ligipääs haridusele ja avalikule ruumile ning kes enamasti suutis suhestuda peale eestikeelse ka mõne võõrkeelse avalikkusega, ning rahvalikke kirjutajaid, kes olid saanud minimaalse hariduse (mida igaüks lugedes täiendas), kelle ligipääs avalikule ruumile oli piiratud (st teatud žanri või rubriigi raames) ning kelle meediakogemus piirdus eesti keelega. ${ }^{1}$ Piiratud ligipääsu all pean silmas mitte täielikku väljajäetust, vaid ligipääsu teatud žanri/rubriigi raames. Tänapäeval näeme samasugust piiratust internetikommentaarides või sotsiaalmeedia aruteludes - ka need tekitavad ühelt poolt kirjutajale tunde, et ta osaleb avalikus ruumis, kuid see osalus on kindlate piirangutega. Konkreetse ajastu inimeste ja avalikkuse suhte uurimiseks on oluline vaadelda ka piiratud avaliku kogemusega osaliste panust.

Järgnevalt keskendungi sellele, kuidas avaldub äratussõnades kogujate suhe avaliku ruumiga.

\footnotetext{
${ }^{1}$ Äratussõnade autorite hulgas oli isikuid, kelle jaoks pääs avalikku ruumi oli võrdlemisi vaba (nt Mihkel Kampmaa), enamikku võib aga käsitleda rahvaliku kirjalikkuse valdkonda kuuluvana.
} 


\section{1. Äratussõnad: põgus ülevaade}

Äratussõnad on minu pandud žanrinimetus, mis lähtub tekstide sissejuhatustes kasutatud fraasidest. Üsna sageli on neis nimetatud sõna/sõnu: „Paar sõna” (EKM ERA, H I 2, 96 < Hans Martinson (1888), H II 20, $254<$ Hans Martinson (1889)), „need sõnad” (EKM ERA, H II 27, 214/5 < Jaan Marmor (1890)), „Paar hüüd sõna” (EKM ERA, H II 31, 812/3 < Kristjan Gross (1889)), „seda sõnakest” (EKM ERA, H II 43, 252 < J. P. (Jaak) Sõggel (1893)), „paar sõnakest” (EKM ERA, H IV 2, 173/4 < Hans Perkson (1889)). Osutatud on ka äratusele: „Palun äratuseks” (EKM ERA, H I 2, $134<$ J. Tiidt (1888)), „Äratuseks oleks mul” (EKM ERA, H II 26, $890<$ Hans Lindeberg (1889)), „Olgu see äratuseks” (EKM ERA, H III 3, 383/4 < Joh. Luthverk (1889); EKM EKLA, f 43, m 7: 5, 1 1/1 < Joosep Järveots (1888)). Paaril korral esinevad need kaks aspekti koos: „Paar sõnakest äratuseks” (EKM ERA, H II 33, 455 < Gustav Sirel (1888)), „Paar sõna üles huideks” (EKM ERA, H III 5, $352<$ Hans Martinson (1888)).

Äratussõnad lisati Hurdale saadetud materjalidele palvega need üleskutsed aruandes avaldada. Hurt sageli ka täitis selle palve, nii olid ilmunud tekstid inspiratsiooniks uute kirjutamisel. Äratussõnad on ühelt poolt rõhutatult kirjalikud, teisalt aga suulised. Suulisusega seovad neid viited hü̈̈dmisele (nt artikli pealkirjas tsiteeritud Juhan Holtsi üleskutse algus, EKM ERA, H I 1, 390 (1889)), verbile, mis kätkeb sõnumi suulist edastust. Samal ajal on tekstid loodud kirjalikku konteksti ehk Hurda aruandeid silmas pidades. Kuna tekstid olid kirjutatud Hurda aruannete koosseisus avaldamiseks, pidid kogujad neid luues arvestama aruannete stiili ja eesmärgiga. Sealjuures ei olnud äratussõnad ainus võimalus kogujate sõnade aruannetesse jõudmiseks. Hurt tsiteeris sageli ka kogujate kirju (Kikas 2017b: 283), ent kui muudel juhtudel valis Hurt ise, mida tsiteerida, siis äratussõnad võimaldasid aruandesse jõuda koguja enda loodud tervikul. Ometi ei tähendanud äratussõnade kirjutamine seda, et need igal juhul avaldati, ka toimetas Hurt avaldatut rohkem või vähem ning mõnikord põimis ta aruandesse piiritletud äratussõnade asemel mõne lõigu sellega kaasnenud kirjast (vt Gustav Sireli kirja (EKM ERA, H II 33, 455 (1888)) kajastust Hurt 1888).

Kokku olen Hurda rahvaluulekogust leidnud 75 äratussõna (sh neli luuletust; 33 teksti on ilmunud Hurda aruannetes). Need on kirja pannud 59 inimest, kellest 13 on saatnud rohkem kui ühe teksti (kõige viljakam oli Hans Martinson: viis teksti). Äratussõnu kirjutasid peamiselt meeskogujad, kuid ka kaks neidu, Marie Punsel ja Liina Jakobson. Tekstid pärinevad aastatest 1888-1895, enamik jääb aastatesse 1888 ja 1889 (vastavalt 22 ja 34 teksti); esimese äratussõna autor on Mihkel Kampmaa. Autorite hulgas on kõige rohkem õpetajaid ja põllumehi - need rühmad on enim esindatud ka kogujate üldhulgas (Jansen 1977: 106-108, 2004: 26-27) -, lisaks neile on kirjutajate hulgas erinevaid ametnikke, rätsepaid, aednikke, üks sõjaväelane ja üks vabrikutööline (kümme kirjutajat ei ole oma eluala avanud).

Äratussõnad on saadetistesse paigutatud nii nagu Hurda korrespondentide eluloodki: enamasti on nad kaaskirja läheduses ning nende eraldatus kaaskirjast võib olla väga erinev (vt Kikas 2017a: 592-595). Osa äratussõnu on ülejäänud kaaskirjast 
vaba ruumiga ja/või jutumärkidega eraldatud, sellele eelneb või järgneb selge avaldamispalve. Teised tekstid on aga rohkem või vähem kaaskirjaga põimunud. Näiteks võib olla tähistatud äratussõnade algus, kuid mitte lõpp; tekst võib olla iseseisev, kuid visuaalselt mitte eraldatud, ning võib ka juhtuda, et Hurdale suunatud kirja sees on paar lauset, mis on adresseeritud üldisemale publikule, kuid nende paari lause järel kõnetab kirjutaja jälle Hurta. Hea näide teksti sisse põimitud äratussõnadest on Jaan Piberi kirjutis, milles võib äratussõnadena arvesse võtta sõrendatud osa, sellele eelneb ja järgneb minavormis kirjeldus:

Mina ollen ikka ja ikka vadanud, et kas meie kihekonas ka midagi aruanetes seisab agga tännini asjata. Mõtlesin siis ma tahan ommeti tee lahdi tehha, ehg tullevad selle peale suuremad sulle mehhed järrele. Kallid Järva Ja anlased egga teiegi keige viimased ei taha olla omma Essivannematte varandust valge ette to omast. Kui nendegi hagganate sees mõnni tuuma terake leida on siis saadan edespidi veel selle sarnatseid... (EKM ERA, H III 1, 133/4 < Jaan Piber (1888))

Nii nagu kogujate elulugude, nii ka äratussõnade iseseisvuse määr viitab sellele, kas koguja soovis oma sõnadega avalikku ruumi jõuda või jättis teksti lõpliku sõnastuse Hurdale (vt Kikas 2017a: 594). Siiski on äratussõnade ja elulugude vahel üks väga suur erinevus: oma äratussõnu pole ükski kirjutaja ümbritsenud enesemadaldusliku väljendusviisiga (vt Kikas 2017a: 587, 592). Näib, et teiste kõnetamine on kogujate jaoks olnud tunduvalt kergem kui oma isiku avalikkusesse asetamine.

\section{2. Äratussõnade žanr intertekstuaalsel väljal}

Äratussõnu kui žanri uurides lähtun Charles L. Briggsi ja Richard Baumani žanrikäsitlusest, mis rõhutab žanride intertekstuaalseid suhteid kultuuri varasemate lausungitega. Žanrid on äärmiselt ambivalentsed ja hägusate piiridega (Briggs, Bauman 1992: 149). See tähendab, et žanriliste markerite lisamine lausungile „toob esiplaanile lausungi kui varasema diskursuse rekontekstualisatsiooni” ning selle kaudu rõhutab teksti looja, et ta omab „autoriteeti, mis võimaldab tal dekontekstualiseerida teatavaid ajaloolisi ja sotsiaalseid seoseid kandva lausungi ja rekontekstualiseerida selle uutesse olukordadesse" (Briggs, Bauman 1992: 148). Kuna teksti ning tema žanri suhe varasemate lausungitega on ambivalentne, tähendab teksti seostamine kindla žanriga intertekstuaalse lõhe (ingl intertextual gap) teket - teksti looja saab vastavalt oma eesmärkidele seda lõhet kas esile tuua või varjutada (Briggs, Bauman 1992: 149).

Briggsi ja Baumani ideid on edasi arendanud kultuuriantropoloog Karin Barber, keda huvitavad žanrid rahvaliku kirjalikkuse sfääris. Ta rõhutab väljaspool avalikku ja kanoonilist tekstiloomet toimuvaid uuendusi ja otsingulisust (Barber 2006b: 385), samuti žanride ja kogukondade vastastikust seotust. Nii märgib ta, et žanri olulisim määratleja on adressaat ning et uute žanride teke on alati seotud uute auditooriumide tekkega. „Žanrid moodustuvad kõnetustsoonis, mille loovad teksti suunatus 
lugejaskonnale ja lugejaskonna suunatus tekstile. Nõnda on uued kõnetusviisid võtmeks uutele žanridele." (Barber 2007: 138)

Ehkki rahvaluulekogujate kirjutised on esmajoones suunatud Hurdale, sisaldavad need žanre, millel on selgelt avalik adressaat. Kolm kõige otsesemalt avalikkusega dialoogis olevat žanri on elulood, mida kogujad kirjutasid vastusena Hurda palvele seoses kogumistöö ajaloo koostamisega (vt Kikas 2017a), kogutud materjalide eessõnad, mis pöörduvad otsesõnu anonüümse lugeja poole, ning äratussõnad. Järgnevalt vaatlen äratussõnu kahe erineva nurga alt: mida ja kuidas nad edastavad ning kuidas ja kelle poole pöörduvad.

\subsection{Praktilised nõuanded ning emotsionaalne retoorika}

Äratussõnad sisaldavad laias laastus kaht tasandit: praktilist ja kujundlikku. Esimene hõlmab nõuandeid selle kohta, mida, millal ja kellelt koguda, või lubadust vajadusel materjali ärasaatmisega aidata. Praktilised nõuanded on kirja pandud pigem lihtsas keeles, ehkki korduste ja loenditega saavutatakse ka poeetiline efekt.

Nüid on sügisine aeg ja pikkad õhtud, kus kõik pere isad ja emad kodus: Juhtige ikka ka vahel vana inimeste juttu vana vara kogumiseks kõiksugu vanade lugude ja sündmuste piale ja meelitage ka neid vanasi laulusi laulma. (EKM ERA, H I 2, $96<$ Hans Martinson (1888))

On veel neid valdasid, külasid, talusid ja saunasid, kus vana vara pere emade ja isade, sauna eitede ja taatide suust suhu jooseb, küll jutus, laulus, vanas sõnas ja mõnes naljakas kõne käänus. (EKM ERA, H III 16, 711/2 < A. J. (1890))

Praktilise poole alla võib arvata ka selle, kui tekstis iseloomustatakse kirjutamisprotsessi või mainitakse erinevaid kirjutusvahendeid. Pikem peatumine kirjutustegevusel on ehk mõeldud julgustusena neile, kes seda tegevust pelgavad.

Võtke sulg või leistik, kumb neist nüüd kellekil käepärast saia om ja pangu midägi kirja [---]. (EKM ERA, H I 2, $134<$ J. Tiidt (1888))

[---] võtke sulg ehk pliiats kätte kes seda vähegi tarvitada oskab [---]. (EKM ERA, H II 26, $890<$ Hans Lindeberg (1889))

Praktiliste nõuannete kõrval esineb aga kõigis tekstides ka emotsioonidele rõhuvat retoorilisust, mille võib jagada kaheks: kujunditeks ja tsitaatideks. Kujundlikul kõnel on äratussõnades peamiselt kolm funktsiooni:

1. Kogumistöö kiireloomulisuse rõhutamine: potentsiaalsed allikad on suremas, rahvaluule on kui küps vili või närtsiv lill.

Läke nüüd ruttu, se aig lät ruttu kondes kõik hilja on, raugemata rutuga, rändavad meie vanad raugakesed auale! (EKM ERA, H II 31, 731/2 < Kristjan Gross (1888)) 
[---] vaatake Põllud on valged leikuselle Se pärast ruttage aegsaste põllule Enne kui vili põldu pudeneb, abi on ädaste tarvis [---]. (EKM ERA, H I 1, $390<$ Juhan Holts (1889))

Astuge minuga ühte nõusse ja noppigem kallid vanavara õiekesi, sest pia võivad nad ära närtsida, kust neid keegi hing tagasi ei too! (EKM ERA, H II 20, 254 < Hans Martinson (1889))

2. Kogutava väärtuse rõhutamine: rahvaluule on sama väärtuslik kui (vana)kuld, (vana)hõbe, pärlid vms. Sageli on väärismaterjal pandud allitereeruma.

Tarvastus on neid kallid pärlid küllald veel peidus! (EKM ERA, H II 25, 301/2 < Jaan ja Johan Viira (1889))

[---] egga teiegi keige viimased ei taha olla omma Essivannematte varandust valge ette toomast. (EKM ERA, H III 1, 133/4 < Jaan Piber (1888))

Ärme laseme mitte villä=päid, kun vana=hõbe aset om, ära pudenda [---]. (EKM ERA, H III 16, 379/82 < Andres Rull (1890))

3. Kogumistöö kui tegevuse kirjeldamine: kogumine on kui töö põllul (vt artikli motot), varanduse väljakaevamine (EKM ERA, H II 37, 537/9 < Tõnu Wiedemann (1892)), lillede noppimine (EKM ERA, H II 20, $254<$ Hans Martinson (1889)) või samba (templi) ehitamine:

Rõngulased ärkage

Üles ühisele tööle,

Kätte jõudnud on see tund!

Ots nüüd tühisele ööle -

Jätke unistust ja und!

Sambaehitaja kätte

Annad killukese vast -

Ta teeb mineviku lätte

Suure samba kildudest!

Aidake siis sammast ehitada, sammast, mida ajahammas ei puutu. (EKM ERA, H II 30, $692<$ P. Grünfeldt (1889))

Paljud äratussõnad on ka tsitaatide, parafraaside või otsese kõne abil mitmehäälseks muudetud. Kui metafooride valik on otseselt seotud kujunditega, mida avalikus ruumis üldiselt rahvaluulekogumisega seoses kasutatakse (pea kõiki ülaltoodud metafoore võib kohata Hurda aruannetes, vt ka Valk 2004), siis teiste häälte kasutamine on võimalus tuua oma teksti midagi selles kontekstis vähem levinut ning muuta oma tekst isikupäraseks. Samas osutavad tsitaadid ja parafraasid sellele, mis kõneleja meelest ühendab teda ja tema adressaate. Näiteks leidub viiteid konkreetsetele autoritele: 
Ärmi lasku kadunud kalli laulu isa soojast südamest tulnud sõnu meelest minna:

Siis kergemini kanname päeva vaeva;

Kui teame, mis Nemad kannatand. (EKM ERA, H II 31, 812/3 < Kristjan Gross (1889))

Osutatakse vanasõnadele:

[---] sest viel on aeg mill koguda võib ärge laske mitte parajad aega möeda minna, sest vana sõna ütleb tau rauda kui raud tuline on pangem seda vanasõna tähele [---] sest Kose kihelkondas on väga rohkest vanavara vanakulda varjul aga mis mitte varjule ei või jäeda. Sest Mida varem seda parem, ütleb vanasõna sest sie aeg saab sisgi tulema et viel mõni kaevaks aga ei ole enam kaevandusi kust kaevata [---] Sest mis täna on tehtud sie on homme hooletu. (EKM ERA, H II 37, 537/9 < Tõnu Wiedemann (1892))

Ja vihjatakse piiblile:

Tööd on palju, aga töö tegijaid väha, paluge Issandad et ta töötegijaid välja läkitäks oma viina mäele. Meie oleme ka ühe niisuguses viinamäel, kus palju palju tööd on seepärast olgem vaprad töötagamisega. (EKM ERA, H III 25, 750/1 < Tõnis Kuresson (1895))

Peale konkreetsete tsitaatide on neis tekstides üheks eriliseks hääleks tulevik.

Tulevik saab Teie peale kui sõrmega näitama, ja ütlema: vaata need mehed on sell ajal vist maganud, et naad hüüdmise healt ei ole kuulnud! (EKM ERA, H II 10, 269 $<$ Jakob Nante (1888))

Et mitte kord ei ütelda: Helme kihelkond on tuim olnud, kui Eesti ajaraamatut tehti ja esivanemaid austati! (EKM EKLA, f 43, m 1: 21, 1 1/2 < Hendrik Anniko (1889))

[---] et me järgi=tuleje mitte ei või ütelde: nemä om laisa ja tuima ollu, ei ole mõisten kulda kambres egä õbet õlma pääle koguda! (EKM ERA, H I 2, $134<$ J. Tiidt (1888))

Ehkki äratussõnades on individuaalset väljendusvabadust võimaldavaid osiseid (valitud tsitaadid, metafoorid), on tekstid sisuliselt väga stereotüüpsed: nad kordavad seda, mida Hurt oma aruannetes ja üleskutseteski ütles, ning kasutavad selleks samu poeetilisi vahendeid. Siinjuures on aga oluline, et metafoore, mille Hurt võttis appi kogumistöö kirjeldamiseks tavainimestele mõistetaval viisil, kasutati peale rahvaluulekogumise ka muu kultuurivälja kirjeldamiseks (nt lisaks tööle vanavarapõllul kirjutavad ajalehed ka tööst kirjanduse või teaduse põllul). Ehk siis rahvaluulekogumise korraldajad hoolitsesid selle eest, et intertekstuaalne lõhe nende üleskutsete ja aruannete ning üldise kultuurivälja vahel oleks minimaalne: retooriliste võtete valik rõhutab rahvaluuleteemade kuulumist üldisesse avalikku ruumi. Kogujad - kelle eesmärgiks oli luua tekst, mis sobiks Hurda aruannetesse - kandsid 
omalt poolt hoolt, et nende kirjapandu sobituks võimalikult hästi kogumistöö korraldajate eelistustega. Et viimane kattus aga üldise kultuurivälja kirjeldamiseks kasutatava kõneviisiga, oli äratussõnade kirjutamine ühtlasi võimalus näidata, et nende autor oskab kirjutada nii, nagu väljendab end iga kaasaegne avalikust diskussioonist huvitatud inimene.

\subsection{Keda kõnetatakse?}

Eespool esile toodud metafoorid on küll äratussõnade oluline osa, kuid samu metafoore on kogujad kasutanud ka Hurdale suunatud kirjades üldiselt. Seega võib sellist kujundikeelt tõlgendada kui viidet avalikule keelekasutusele, ent tegu ei ole üksnes äratussõnade kui žanri eristava tunnusega. Sellele žanrile eriomane on aga - nagu eespool välja tõin - spetsiifilise kõnetatava nimetamine (just adressaadi muutus Hurdale suunatud kirjas aitab määrata nõrgalt eristatud äratussõnade piire). Järgnevalt heidangi pilgu sellele, kuidas kogujad on piiritlenud äratussõnade kõnetatavaid.

Äratussõnade adressaat on enamasti geograafiliselt määratletud. Kõnetatava rühma piirkonnaks võib olla nii vald, kihelkond kui ka mõni suurem ala. Nii pöördub mitu kogujat Läänemaa inimeste poole (EKM ERA, H III 4, 585/6 < K. Laasi (1888); EKM EKLA, f 43, m 25: 8, 1 1/1-1/2 < J. Veidermann (1888)), Villem Piir pöördub aga „ôhtupoolsete Viljandlaste” poole (EKM ERA, H III 14, 317 (1889)). Mõnikord luuakse mitme väiksema piirkonna loendiga maa-ala üldistus. Näiteks loetleb Hans Martinson Pärnu kihelkonna eri paiku: „Armsad Uullased, Surilased, Reidlased ja Randlased, Teie isamaapojad ja tütred" (EKM ERA, H III 5, 352 (1888)).

Mitmel juhul on kõnetatava kogukonna paik alliteratsiooni abil esile tõstetud: „[---] nüid on veel aeg kus Kursis seda kallist kulda saadaval on” (EKM ERA, H II 27, 214/5 < Jaan Marmor (1890)); ,[---] ma ei sa aru miks pärast uinuvad südikad Sangastelased” (EKM ERA, H II 31, 731/2 < Kristjan Gross (1888)); „Tormalased astuge välja, ma tean teil on mehi, tulge tormilise hooga" (EKM ERA, H III 3, 273/4 $<$ P. F. Sorgus (1889)); „Jätke, armsa suguvelle, kik parteiliku mõtte ja nuusime terve kihelkond Kihnuküläst Kiisälööveni ja Riumaküläst Riidäjä piirini läbi” (EKM ERA, H III 16, 379/82 < Andres Rull (1890)). Taga-Kaukaasias elav Jakob Mihkelson kirjeldab oma päritolupaiga pärimusmaastikku allitereeruvalt:

On ju seal koht kus vanakurat va Kavala Hansu kõbarasse kulda kannud; ka mitte kaugel Kikepera kivistik, kus kurat koleda kivi kandmaga läbi käinud, mida ta põlles kannud, paraku aga parajaste seal paikas läinud vana poisi pihastanud põlle paelad puruks - Kaevigu vana kulda Kavala Hansu kübara kohalt ja kuradi kivi kandma keskelt! - Seal on tõesti veel vaevaga veetud vanavara. (EKM ERA, H II 45, 517/8 < Jakob Mihkelson (1892))

Kui vaadata kõnetaja ja kõnetatava suhet, siis enamasti kuulub üleskutsuja ise selle kogukonna hulka, kellele ta oma sõnumi adresseerib. Valla- või kihelkonnapõhistes pöördumistes kõnetatakse oma piirkonna või naabruse inimesi, avaramates piiritlustes on koguja asukoht suurema terviku osa. Harvematel juhtudel on äratus- 
sõnade autoriks inimene, kes ise enam kõnealuses piirkonnas ei ela (elab hoopis linnas või diasporaas), kuid kes muretseb oma päritolupaiga alaesindatuse pärast (nt EKM EKLA, f 43, m 8: 5, 1 1/1-1/2< Mihkel Kampmann (1888)). Siiski on oluline, et kõnetatavaks pole mitte mainitud paiga elanikkond tervikuna, vaid eelkõige need, kes oskavad näha seda paika suurema (rahvus)terviku osana.

Paiga suhe seda ümbritsevaga võib äratussõnades esile tulla kahel moel. Esiteks kohaliku ja üldise/rahvusliku kõrvuti asetamise kaudu. See võib tulla esile juba teksti alguses olevas kõnetuses, näiteks: „Auusad eesti vennad ja õed Kursis” (EKM ERA, H II 27, 214/5 < Jaan Marmor (1890); vt ka EKM ERA, H III 5, 352 < Hans Martinson (1888)). Viide kohalikus peituvale üldisele, st kogu kodumaad hõlmavale tasandile võib ilmneda ka teksti keskel:

Siin pean ma aga Kodavere suurema sulemeestele meelde tuletama et praegu aeg vanavara korjamiseks käes on ja selle pärast ärge pange ka Teie mitte omi sulgi tindipoti äärde rostetama vaid võtke kindlaste nad pihku ja pistke vanavara mida Kodaveres vist küll leida saab olema paberisse, sest see on iga isama poja ja tütre püham kohus. Eesti Kultse aja mälestusi alal hoida. (EKM ERA, H II 27, 888a/b < Joosep Liiv (1888))

Teiseks võimaluseks paiga avaramasse konteksti asetamiseks on võistlusmomendi rõhutamine. Rahvaluulekogumise korraldajad kasutasid rahvusele viitamiseks nn kaardimetafoori: rahvustervik jagunes väiksemateks võrdseteks osadeks ning eesmärgiks oli „valgete laikudeta” vanavarakaart, st see, et kogutaks võrdselt kõikidest kihelkondadest. Ka kogujad oma tekstides väljendavad hirmu selle ees, et nende kodupaik jääb nn valgeks laiguks ning pälvib seetõttu teiste piirkondade elanike ja/ või tuleviku pahameele:

Pangu Paistu vennad ja õed seda tähele, kuidas siin ja sääl teie naabri kihelkondades pojad ja tütred usinusega vanavara kaevanduste kallal tööd teevad, ja meie seisame sest külmalt kaugel - käed rüppes! (EKM EKLA, f 43, m 1: 8, 1 1/1 < Jaan Ainson (1889))

Ehkki adressaadi peamiseks tunnuseks on tema kuulumine kindlasse kohta, esineb üleskutsetes ka muid iseloomustajaid, näiteks tuuakse esile kõnetatava kirjaoskus, sugu ja vanus.

Palju on pöördutud kirjutamisega seotud elualaga inimeste (kirjanike, õpetajate ja (üli)õpilaste) poole. Sellisele auditooriumile apelleerivad nii kolleegide ja õpingukaaslaste poole pöörduvad õpetajad (nt „Auustatud ametivennad pange käed adra külge ärge seiske ega viitme oma sui aega asjata ära”, EKM ERA, H III 13, $162<$ Gustav Anniko (1893)) kui ka need kogujad, kes määratlevad end kirjutamisega mitte seotud eluviisi esindajana, nt: „Teie Veike Maarja kirjanikud koolmeistrid ja valla kirjutajad kes Teie sagedaste uusi laulusi loote ja mõnedgi ju oma luuletuste eest esimise auu hinna olete saanud" (EKM ERA, H III 16, 105/6 < Jüri Puurmann (1888)). Mõnikord on viidatud eri elualade esindajatele, rõhutades nii üleskutse laiapõhjali- 
sust: „Viimaks pian veel armsa Kadrina rahvale südameliku palve ette panema, olgu ta sule mees ehk põllu mees" (EKM ERA, H I 1, $90<$ Kaarel Kleinmann (1888)).

Siiski ei ole kirjutamistegevus alati seotud vastavate elualadega, võidakse pöörduda ka kõigi kirjutajate poole: „Austatud Harju-Jaani kihelkonna sulesõbrad ja paberi piinajad" (EKM EKLA, f 43, m 22: 50, 1 1/2 < Heinrich Tiedermann (1889)), „Kas ei ole meil Juurulastel vana vara korjata? Kas ei ole meil kirjutus materjali või ei ole meil mehi kes kirjutada mõistavad" (EKM ERA, H III 3, 491/3 < Jüri Oras (1889)). Mitmes pöördumises võib näha kirjutusvahendi inimlikustamist, nt: „Armse Karksi suguvelle ja sõsare! Misperäst panete oma sule kurtme..." (EKM ERA, H I 2, 134 < J. Tiidt (1888)). Või käsitletakse kirjutusvahendit kirjutaja metonüümiana: „Teie laisad käed ja roostetanud suled!" (EKM ERA, H IV 2, 173/4 < Hans Perkson (1889))

Omaette teema on adressaadi sugu. See on selgelt tähistatud kahes üleskutses konkreetse piirkonna neidudele (EKM ERA, H III 2, $480<$ Viilip Klaas (1888); EKM ERA, H II 28, 733 < Liina Jakobson (1890)). Ülejäänud üleskutsed on kas sooliselt neutraalsed (mõeldud nt sangastelastele, tormalastele jne), suunatud pigem meestele („Armsa Tarvastu velle!”, EKM ERA, H III 16, 379/82 < Andres Rull (1890)) või mõlemale soole („Lõpeks hüüan veel Urvaste ärksamatele poegadele ja tütardele”, EKM EKLA, f 43, m 12: 46, 13/6 < H. Lellep (1890)).

Mõningatel juhtudel on adressaat tähistatud ka vanuseliselt. Nii tuuakse vahel esile, et pöördutakse just kohalike noorte poole, „sest vanad inimesed ju palju kirjutada ei oska, aga selleks on nad nooremaid õppida lasknud" (EKM ERA, H I 2, 96 < Hans Martinson (1888)). Ka see, kui pöördutakse neiude-peiude või noorte meeste ja neiude poole, eeldab, et kõnetatavad on noored (nt EKM ERA, H III 13, $162<$ Gustav Anniko (1893); EKM EKLA, f 43, m 1: 21, 1 3/5 < Hendrik Anniko (1889); EKM ERA, H II 17, 303/4 < A. K. Saalist (1889)). Vaid 13-aastane Marie Punsel pöördub endast vanemate inimeste poole: „Aidaku kõik Eesti Vennad ja õed, kes minust vanemad ja targemad on" (EKM ERA, H III 2, $577<$ Marie Punsel (1889)).

Väike osa äratussõnadest on suunatud geograafiliselt piiritlemata auditooriumile, näiteks lihtsalt kõigile vanavarakorjajatele (EKM ERA, H II 27, 755/6 < Heinrich Käär (1889), H III 21, $330<$ Heinrich Käär (1894); EKM ERA, H III 16, $240<$ Martin Eikelmann (1889)), kõigile eestlastele (EKM ERA, H III 16, 711/2 < A. J. (1890); EKM EKLA, f 43, m 14: 34, 1 1/1 < Hans Martinson (1888); EKM ERA, H III 2, 577 < Marie Punsel (1889)) või mõne konkreetse eluala esindajatele: Johannes Juurikas ärgitab metsavahte (EKM ERA, H II 22, 693/4 (1889)), Viilip Klaas rätsepaid (EKM ERA, H III 2, 487/8 (1889)). Kokku on geograafiliselt määratlemata auditooriumi poole pöördunud üksteist kogujat, ent vaid nelja jaoks on see jäänud ainsaks auditooriumiks (EKM ERA, H II 27, 755/6 < Heinrich Käär (1889), H III 21, $330<$ Heinrich Käär (1894); EKM ERA, H III 16, $240<$ Martin Eikelmann (1889); EKM ERA, H III 16, 711/2 < A. J. (1890); EKM ERA, H III 2, $577<$ Marie Punsel (1889)). Ülejäänud on teistes äratussõnades kõnetanud mõnd kohalikku kogukonda. Mõnel juhul on koguja lähtunud oma adressaadi piiritlemisel isiklikust kogemusest. Johannes Juurikas kõnetab metsavahte, kuna tema peainformant on metsavaht, rätsep Viilip Klaas leiab, et just tema amet soodustab materjalile ligi pääsemist. Liina Jakobson tunneb vajadust kõnetada omakandi sookaaslasi, rõhutamaks rahvaluulekogumise 
kuulumist kasulike ajaveetmisvõimaluste hulka. Eriti aga näib üldise adressaadiga tekstide taustaks olevat koguja ambitsioon katsetada, kui avara auditooriumi kõnetamine on talle jõukohane. Sedasorti tekstid on pakkunud Hurdale ilmselgelt kõige vähem huvi (nende adressaat sarnanes ju tema enda üleskutsete omaga) - ainus üldsusele suunatud üleskutse, mis ka Hurda aruannetesse jõudis, on Mihkel Eikelmanni konkreetse teema (jahipärimus) kogumisega seotud tekst (vt Hurt 1889).

Seega on adressaati peamiselt piiritletud teatud kohasuhte kaudu, kuid eeldatakse ka tema kirjaoskust, noorust ning seda, et ta suhestub peale kohaliku piirkonna ka üldise rahvustervikuga. Sealjuures on see, kuidas äratussõnade kirjutajad on lahendanud pinge kohaliku ja rahvusliku tasandi vahel, seotud nii Barberi ideega žanride ja kogukondade seostest kui ka žanripiiride ambivalentsusega, millele on osutanud Briggs ja Bauman. Äratussõnad pakuvad kogujatele võimaluse suhestada neid ümbritsev kohalik kogukond mingi üldise tervikuga. Samal ajal on see kohalik kogukond, kelle poole pöördutakse, juba mõjutatud sellest, kuidas nad tajuvad rahvustervikut. Äratussõnadega kõnetataval ei ole üksühest vastet tegelikkuses - see on kohaliku kogukonna avalik-üldine kuvand, mille esiletoomise kaudu soovivad kogujad märku anda, et ka „meie siin saame aru, mis on kaasaegses maailmas oluline”.

Žanripiiride ambivalentsuse osas tuleb aga meeles pidada üleskutse kui pöördumisviisi tavalisust tollases avalikus ruumis (näiteks kutsuti üles asutama erinevaid seltse, looma korraldustoimkondi, koguma raha, tegema kaastööd luuleantoloogiatele jms). Kui pidada silmas, et avalikkuse üks peamisi tunnuseid on selle mobiliseeritavus ühise eesmärgi nimel (Gal, Woolard 2001: 8; Bauman 2001: 60), on üleskutse kui tekstiliik tugevalt seotud avalikkuse kui kogukonna käigushoidmisega.

Seega peab žanri esiletõstes arvestama ka erinevate tõlgendusraamidega. Kui vaadelda äratussõnu rahvaluulekogujate loodud tekstiväljal, võib kõneleda äratussõnadest omaette žanrina. Need eristuvad nii eesmärgi kui ka adressaadi piiritlemise poolest teistest samas kontekstis loodud avaliku adressaadiga tekstidest (näiteks elulood võimaldavad oma isiku projitseerimist avalikku ruumi, samas kui otsesõnu lugeja poole pöörduvad saatesõnad tegelevad materjali tutvustamisega). Kaasaegse avaliku diskursuse kui terviku taustal muutub oluliseks äratussõnade põimitus sellesse tervikusse. Selgelt piiritletud žanri asemel tõuseb esile kõnetusviiside, kõnekujundite ja tekstiliikide levimine eri kontekstidesse ja erineva taustaga kirjutajate tekstidesse.

\section{Kokkuvõtteks}

Artiklis käsitlesin üht konkreetset rahvaluulekogumise raamistuses ringelnud žanri - äratussõnu. Nende kirjutamisel võis kogujate jaoks olla erinevaid funktsioone. Esiteks on tegu otseselt üleskutsetega: tekstidega, mille eesmärgiks on panna kedagi kolmandat soovitud suunas tegutsema. Sealjuures võib teiste tegutsema ärgitamine tuleneda nii soovist kaitsta (veel) tõhusamalt kodukoha au kui ka kirjutaja-üleskutsuja lootusest leida kohalikke mõttekaaslasi, kellega kogemusi vahetada. Teiseks tegelevad need tekstid mingi auditooriumi/kogukonna piiritlemisega, millega rõhu- 
tatakse ühelt poolt kindla kogukonna asendit suuremas rahvusrühmas ning teisalt kirjutaja enda suhet selle rühmaga (ning rühma kaudu üldiselt eestlaskonnaga). Kolmandaks on äratussõnad kirjutaja jaoks võimalus näidata, et ta valdab avalikkuses kasutatavat kujundikeelt, ning kuna kõneleja esindab selles kontekstis laiemat kogukonda, siis on äratussõnad ühtlasi kinnituseks, et vastavas kogukonnas osatakse sel viisil kõneleda.

Benedict Anderson on märkinud, et kujutletud kogukond tugineb ühisele (ajalehe)lugemise kogemusele (2006: 35). Äratussõnad aga näitavad, et ainult lugemisest ei piisa - sellest olulisemgi on võimalus ise lugemismaterjali luua (sama on täheldanud nt Barber 2006a: 16). Tõsi, sissejuhatuses osutasin kogujate kirjutiste ambivalentsele suhtele avaliku ruumiga: ehkki ühelt poolt on nad seotud kogumistöö korraldajate avalikus ruumis ilmunud kirjutistega, on nad sama tugevalt seotud ka nn rahvaliku kirjalikkuse sfääriga. Lõpetuseks olekski paslik viimast seost mõnevõrra avada.

Kõige tuntum ja enim kasutatav avaliku kirjutamise võimalus rahvalikele kirjutajatele XIX sajandil oli ajalehtedele kaastöö tegemine. Ea Jansen on rõhutanud tolleaegse ajakirjanduse rahvalähedust ja nimetanud ajalehtedele sõnumite saatmist tollase eestlase „tüüpiliseks vaimse eneseavaldamise vormiks” (Jansen 2004: 84-85). Kuigi rahvalikud kirjutajad saatsid ajalehtedele väga erinevat materjali (luuletusi, jutte, arvamuslugusid jne), oli kõige suurem tõenäosus saada avaldatud nn kohalike sõnumite rubriigis, seega ligipääs oli piiritletud konkreetse rubriigiga. Teine oluline kõigile avatud kirjutamisvõimalus oli rahvaluulekogumises osalemine. Ehkki väliselt oli rahvaluulekogumise raames kirjutamine temaatiliselt piiritletud, saadeti Hurdale väga erinevaid tekste, neist mõned meenutavad žanrilt ajalehe arvamuslugu. See oli võimalus kirjutada tunduvalt pikemaid ja erinevate teemadega seotud tekste, ehkki nende avaldamise tõenäosus oli väike.

Sageli täitsid samad inimesed mõlemaid rolle, st olid nii kohalikud kirjasaatjad kui ka rahvaluulekogujad, ning eri ülesandeis positsioneeriti end sarnaselt: ajalehe kirjasaatja asetas oma kodupaiga üldisele kaardile (kõrvutades kohalikke teateid teistest paikadest saadetud sarnaste sõnumitega) ning rõhutas selle kaudu, et ka tema kodukohas mõeldakse kaasaegsete teemade üle ning osatakse avalikule ruumile sobivalt kõneleda. Samuti võis kohalike sõnumite hulka sattuda erinevaid kindla paiga elanikele suunatud üleskutseid (nt ettepanek asutada karskusselts), mille adressaadid olid piiritletud sarnaselt äratussõnade omadega (rõhutatakse nii kohalikkuses peituvat üldist elementi kui ka seda, et naabervallad on oma seltsi juba asutanud).

Seega oli rahvalikel kirjutajatel mitmeid kanaleid, mille kaudu oma ideid väljendada. Samas olid kõik need võimalused oma piirangutega ning enamik rahvalike kirjutajate avaliku adressaadiga tekstidest ei jõudnud kunagi avalikkuseni. Selle põhjused võivad peituda kõigis neljas Hilli nimetatud avalikkust piiritlevas aspektis: nii valitud ruumis, teemas, kõnelejas kui ka stiilis (vt Hill 2001: 87-93). Ajalehtede kaastöölised võisid püüelda avaldamist väljaspool neile avatud rubriike, kirjutada anakronistlikus stiilis või teemal, mida avalikus ruumis üldiselt ei puudutatud (selliste rahvaluulekogujate kirjutiste kohta vt Kikas 2014: 320-321). Enamasti oli määravaks asjaoluks kõneleja isik: rahvalik kirjutaja jõudis avalikku ruumi vaid siis, kui 
keegi teine oli valmis tema sõnumit edastama (ajalehesõnumite valiku tegi toimetaja, äratussõnade valiku Hurt). Äratussõnad on sellel taustal vägagi eriline žanr. Paigas on nii stiil (kirjutajad tajuvad, kuidas on kombeks kõneleda), teema (nad kõnelevad sellest, mida peetakse üldiselt oluliseks) kui ka ruum (saadetud Hurdale ning sageli ümbritsetud konkreetse avaldamispalvega). Samas jääb ka nende tekstide juures õhku küsimus kõneleja positsioonist: need tekstid jõudsid küll ajakirjandusse, kuid ilmusid alati kellegi teise teksti sees jutumärkides ning tsiteerimise eesmärgiks oli tsiteerija sõnumi võimendamine.

Rahvalike kirjutajate tekstide ambivalentne positsioon võimaldab avalikku ruumi vaadelda vähemalt kahel erineval moel. Ühelt poolt võib võtta lähteks selle, mis sai avaldatud: nii tõuseb keskmesse küsimus sellest, mida ajalehetoimetajad või Hurt pidasid vajalikuks just rahvalike kirjalike sõnade kaudu väljendada. Teisalt aga, suhestades avaldatut avaldamata jäänuga, tõuseb esiplaanile see, mida erinevad inimesed avalikust ruumist ootasid, omaks võtsid ja edasiarendamise väärseks pidasid. Antud artiklis olen keskmesse seadnud just teise võimaluse: äratussõnad sellistena nagu nad on nähtavad käsikirjalehekülgedel, kogujate muude tekstide vahetus läheduses, kõigi nende kõhkluste ja ambitsioonidega.

Artikli valmimist on toetanud Euroopa Liit Euroopa Regionaalarengu Fondi kaudu (Eesti-uuringute Tippkeskus), see on seotud Eesti Teadusagentuuri uurimisprojektiga IUT22-5 „Folkloori narratiivsed ja usundilised aspektid".

\section{ARHIIVIALLIKAD}

\section{Eesti Kirjandusmuuseumi (EKM) Eesti Kultuurilooline Arhiiv (EKLA)}

f 43 - Kirjad Jakob Hurdale.

ERA, H - Jakob Hurda rahvaluulekogu Eesti Kirjandusmuuseumi Eesti Rahvaluule Arhiivis

\section{KIRJANDUS}

Anderson, Benedict 2006. Imagined Communities: Reflections on the Origin and Spread of Nationalism. London-New York: Verso.

Barber, Karin 2006a. Introduction: Hidden innovators in Africa. - Africa's Hidden Histories. Everyday Literacy and Making the Self. Toim K. Barber. Bloomington: Indiana University Press, lk 1-21.

Barber, Karin 2006b. Writing, genre and a schoolmaster's inventions in the Yoruba provinces. - Africa’s Hidden Histories. Everyday Literacy and Making the Self. Toim K. Barber. Bloomington: Indiana University Press, lk 385-415.

Barber, Karin 2007. The Anthropology of Texts, Persons and Publics. Oral and Written Culture in Africa and Beyond. Cambridge: Cambridge University Press.

Bauman, Richard 2001. Representing native American oral narrative. The textual practices of Henry Rowe Schoolcraft. - Languages and Publics. The Making of Authority. Toim Susan Gal, Kathryn A. Woolard. London-New York: Routledge, lk 46-68. 
Briggs, Charles L.; Bauman, Richard 1992. Genre, intertextuality and social power. - Journal of Linguistic Anthropology, kd 2, nr 2, lk 131-172.

Gal, Susan 2001. Linguistic theories and national images in nineteenth-century Hungary. - Languages and Publics. The Making of Authority. Toim S. Gal, Kathryn A. Woolard. London-New York: Routledge, lk 30-45.

Gal, Susan; Woolard, Kathryn A. 2001. Constructing languages and publics. Authority and representation. - Languages and Publics. The Making of Authority. Toim S. Gal, K. A. Woolard. London-New York: Routledge, lk 1-12.

Hill, Jane H. 2001. Mock Spanish, covert racism and the (leaky) boundary between public and privat spheres. - Languages and Publics. The Making of Authority. Toim Susan Gal, Kathryn A. Woolard. London-New York: Routledge, lk 83-102.

Hurt, Jakob 1888. Viiestõistkümnes aruanne Eesti vanavarakorjamisest ja keelemurrete uurimisest. 27. Oktobril 1888. - Olevik 31. X, lk 1, 7. XI, lk 1; Postimees 1. XI, lk 1, 3. XI, lk 1-2.

Hurt, Jakob 1889. Neljaskümnes neljas aruanne Eesti vanavara korjamisest ja keelemurrete uurimisest. 16. Augustil 1889. - Olevik 21. VIII, lk 2; Postimees 22. VIII, lk 1.

Jansen, Ea 1977. Eesti talurahva rahvusliku teadvuse kujunemisest XIX sajandil. - Eesti talurahva sotsiaalseid vaateid XIX sajandil. Toim J. Kahk. Tallinn: Eesti NSV Teaduste Akadeemia, lk 67-123.

Jansen, Ea 2004. Vaateid eesti rahvusluse sünniaegadesse. Tartu: Ilmamaa.

Kikas, Katre 2014. Folklore collecting as vernacular literacy: Establishing a social position for writing in the 1890s Estonia. - Vernacular Literacies - Past, Present and Future. Toim Ann-Catrine Edlund, Susanne Haugen, Lars-Erik Edlund. Umeå: Umeå University, lk 221-235.

Kikas, Katre 2017a. Rahvaluulekogujate elulood Jakob Hurda rahvaluulekogus. - Keel ja Kirjandus, nr 8-9, lk 584-599.

Kikas, Katre 2017b. Rahvaluulekogumine epistolaarses kontekstis. Helene Maaseni kirjad Jakob Hurdale. - Keel ja Kirjandus, nr 4, lk 272-290.

Kingisepp, Valve-Liivi 2001. Eesti keele esimestest kirjapanekutest ja kirjaviisidest. - Oma Keel, nr 1, lk 5-13.

Valk, Ülo 2004. On the discursive foundations of Estonian folkloristics: a farmer's field of vision. - Everyday Life and Cultural Patterns. International Festschrift for Elle Vunder. (Studies in Folk Culture 3.) Toim Ene Kõresaar, Art Leete. Tartu: Tartu University Press, lk 265-272.

Valk, Ülo 2008. Saksad ja varavedajad: eesti muistendite sotsiaalsest orientatsioonist. - Kes kõlbab, seda kõneldakse. Pühendusteos Mall Hiiemäele. (Eesti Rahvaluule Arhiivi toimetused 25.) Koost Eda Kalmre, Ergo-Hart Västrik. Tartu: Eesti Kirjandusmuuseumi Teaduskirjastus, lk 57-73.

Katre Kikas (snd 1981), MA, Eesti Kirjandusmuuseumi folkloristika osakonna teadur (Vanemuise 42, 51003 Tartu), katreki@folklore.ee 


\title{
Awakening calls of folklore collectors addressing the public
}

\author{
Keywords: publics, folklore collecting, Jakob Hurt, $19^{\text {th }}$ century Estonia, vernacular \\ literacy
}

The article focuses on the ambivalent relationship between the public space and the folklore collecting campaigns of the last decade of the $19^{\text {th }}$ century. On the one hand, those campaigns were heavily embedded into public space as all information regarding the collecting as well as feedback to collectors was given through newspapers. But if we look at the position of ordinary collectors in regard of public space, the picture is much more ambivalent - though most of their writings failed to be published, they still seemed to regard writing in this context as a possibility to write publicly. To reflect this ambiguity I have called such writing half-public.

Still, there were some genres that made their way from half-public to real public space. One of such was the 'awakening calls' (äratussõnad), i. e. texts written by folklore correspondents with an intention to enliven collecting activity in the area they felt attached to. The texts were sent to the leader of the campaign Jakob Hurt, who was expected to publish them as part of his collection reports. I consider this genre from two viewpoints: what those texts are about and how the addressees of the texts are construed. As a starting point I take the ambiguity of genre boundaries as stated by Charles L. Briggs and Richard Bauman, and the mutual relationship between genres and communities as stated by Karin Barber.

There are at least three different approaches leading to the meaning of this genre. On the one hand, we can take the awakening calls as a separate genre with its own meanings and goals. On the other hand, we can examine it in the contexts of contemporary public written space, which reveals that the language and generic conventions of the awakening calls are quite common in other public genres as well; thus, instead of analysing it as a separate genre we can rather talk about the spread of similar genre features in the repertoires of different communities. And thirdly, we can look at this genre as part of contemporary vernacular literacy and ask about the possibility of ordinary people of the time discussing their messages in public.

As a conclusion we can say that the texts have multiple goals. The first is rather obvious - they are calls, texts which aim to mobilize other people. But besides this those texts also deal with the construction of certain communities and discuss the relationship between those communities and the national whole. Thirdly, those texts enable the writer to show that he/she (and his/her community) know how one should talk in public, and in doing so, to emphasise that this person/community is part of the public space.

Katre Kikas (b. 1981), MA, Estonian Literary Museum, Department of Folkloristics, Researcher (Vanemuise 42, 51003 Tartu), katreki@folklore.ee 